\title{
ANALISIS PEMBERIAN TABLET FE DENGAN KOMBINASI VITAMIN C DAN VITAMIN A TERHADAP ANEMIA PADA SISWI SMU DI KECAMATAN MEDANG DERAS KABUPATEN BATUBARA
}

\author{
Yulina Dwi Hastuty, Dodoh Khodijah \\ Jurusan Kebidanan Poltekkes Kemenkes Medan
}

\begin{abstract}
Abstrak
Kadar $\mathrm{Hb}$ yang rendah (anemia) merupakan salah satu masalah kesehatan yang sering dialami oleh seorang wanita tidak terkecuali remaja. Remaja putri merupakan salah satu kelompok yang rawan menderita anemia dibandingkan dengan remaja laki-laki karena remaja perempuan setiap bulan mengalami siklus menstruasi dan memiliki kebiasaan makan yang salah. Anemia pada remaja akan berdampak pada penurunan konsentrasi belajar, penurunan kesehatan dan gangguan pertumbuhan sehingga tinggi badan dan berat badan tidak mencapai normal. Kehamilan pada usia remaja juga memberi efek yang panjang yaitu menyebabkan kematian ibu, bayi, atau risiko melahirkan bayi dengan BBLR (Berat Bayi Lahir Rendah), selain itu dapat menyebabkan penurunan antibody sehingga mudah sakit karena terserang infeksi dan dapat menimbulkan kelelahan, badan lemah, penurunan kapasitas/kemampuan atau produktivitas kerja Di Indonesia prevalensi kejadian anemia remaja cukup tinggi mencapai $57,1 \%$. Penelitian ini bertujuan untuk melihat perbandingan peningkatan kadar $\mathrm{Hb}$ antara pemberian Fe kombinasi dengan Vitamin A atau Vitamin C dengan hanya pemberian Fe. Jenis penelitian ini adalah eksperimen dengan rancangan randomized control trial design pretest posttest control group, Jumlah Sampel Sebanyak 105 yang dibagi dalam 3 kelompok perlakuan. Data dianalisis dengan menggunakan uji T dan Anova. Hasil penelitian menunjukkan bahwa pemberian $\mathrm{Fe}$ dengan vitamin A memiliki peningkatan rerata $\mathrm{Hb}$ yang lebih tinggi dibanding 2 kelompok perlakuan lainnya.
\end{abstract}

Kata kunci : anemia, kadar Hb, Fe, Vitamin A, Vitamin C

\section{PENDAHULUAN}

Anemia adalah suatu keadaan dimana menurunnya hemoglobin $(\mathrm{Hb})$, hematokrit, dan jumlah sel darah merah di bawah nilai normal (Price S.A, 2007). Kadar Hb yang rendah merupakan salah satu masalah kesehatan yang sering dialami oleh seorang wanita tidak terkecuali remaja (Khadafi dkk, 2015). Remaja putri merupakan salah satu kelompok yang rawan menderita anemia. Remaja putri berisiko lebih tinggi terkena anemia dibandingkan dengan remaja laki-laki karena alasan pertama remaja perempuan setiap bulan mengalami siklus menstruasi dan alasan kedua yaitu karena prilaku makan.

Penyebab anemia adalah akibat faktor gizi dan non gizi. Faktor gizi terkait dengan defisiensi protein, vitamin, dan mineral, sedangkan faktor non gizi terkait penyakit infeksi. Protein berperan dalam proses pembentukan hemoglobin, ketika tubuh kekurangan protein dalam jangka waktu lama pembentukan sel darah merah dapat terganggu dan ini yang menyebabkan timbul gejala anemia (Masthalina H dkk, 2015).

Data Riset Kesehatan Dasar (Riskesdas) tahun 2013 menunjukkan proporsi kejadian anemia pada kelompok usia 15-24 tahun sebesar 18,4\% dari seluruh kelompok usia 1-75 tahun, sedangkan dilihat dari proporsi kejadian anemia berdasarkan jenis kelamin diketahui perempuan sebesar 23,9\%. Di Indonesia, prevalensi dikalangan remaja adalah $57,1 \%$, wanita usia subur $(27,9 \%)$ dan ibu hamil $(40,1 \%)$. Penyebab utama anemia gizi di Indonesia adalah asupan zat besi (Fe) yang rendah(Utami, 2013).

Status zat besi di dalam tubuh manusia tergantung pada penyerapan zat besi tersebut. Hal -hal yang dapat meningkatkan penyerapan besi diantaranya adalah enhancer yang berperan besar terhadap penyerapan zat besi. Enhancer zat besi diantaranya vitamin $\mathrm{C}$ dan vitamin A. Vitamin C sebagai enhancer karena vitamin C membantu penyerapan besi non heme dengan merubah bentuk feri menjadi fero yang mudah diserap (Masthalina dkk 2015). Sedangkan interaksi Vitamin A dan - karoten dapat membentuk suatu kompleks dengan besi untuk membuatnya tetap larut dalam lumen usus dan mencegah efek penghambat dari fitat dan polifenol pada absorpsi besi ( Asterina, Sari YK, 2009).

Upaya pencegahan dan penanggulangan anemia yang telah dilakukan selama ini lebih banyak ditujukan pada ibu hamil seperti pemberian tablet Fe selama 3 bulan (90 butir), sedangkan remaja putri secara dini belum terlalu diperhatikan. Beberapa peneliti menemukan bahwa penyerapan zat besi dengan kombinasi Vitamin A dapat meningkatkan kadar Hb ( Asterina, 2009, Permaesih dkk, 
2011) ) begitu juga pemberianFe dengan Vitamin $\mathrm{C}$ memiliki peningkatan yang cukup signifikan (Utama dkk, 2013, Pradanti dkk, 2015) namun belum diketahui mana diantara kedua vitamin tersebut yang memiliki efek lebih besar dalam meningkatkan kadar $\mathrm{Hb}$ pada kasus anemiaStudi pendahuluan diklinik bersalin yang ada di Kecamatan Medang Deras tahun 2015 menunjukkan bahwa hampir $80 \%$ ibu hamil remaja menderita anemia. Hasil pengamatan yang dilakukan di SMA N I Kecamatan Medang deras ditemukan $60 \%$ menunjukkan tanda-tanda gejala anemia seperti konjungtiva yang pucat, mengeluh sering pusing dan mereka belum pernah mengkonsumsi Fe. Penelitian ini bertujuan untuk melihat perbandingan peningkatan kadar $\mathrm{Hb}$ antara pemberian Fe kombinasi dengan Vitamin $\mathrm{A}$ atau Vitamin $\mathrm{C}$ dengan hanya pemberian $\mathrm{Fe}$

\section{METODE PENELITITAN}

Penelitian ini merupakan penelitian eksperimental dengan rancangan randomized controlles trial desain pretest posttest control group (Sastroasmoro S, 2002) Dalam penelitian ini dilakukan pada 3 (tiga) kelompok yaitu kelompok perlakukan I diberikan Suplementasi besi (Fe) dan kelompok perlakuan II diberikan suplementasi (Fe -vitamin C) sedangkan kelompok perlakukan III diberi suplementasi ( $\mathrm{Fe}$ - vitamin A). Perlakuan diberikan selama 4 minggu (1 bulan). Penelitian dilakukan di Kecamatan Medang Deras Kabupaten Batubara yaitu di SMA N 1, SMA Swasta Citra dan Sekolah Aliyah Al-Wasliyah Kecamatan Medang Deras dan dikalkukan dilaksanakan mulai dari Pebruari - Oktober 2016. jumlah sampel sebanyak 120 orang yang dibagi menjadi 3 kelompok perlakuan sehingga masing-masing kelompok berjumlah 40, namun dalam perjalanananya ada yang mengundurkan diri (Drop Out) sehingga total sampel akhir adalah 105 orang. Pemeriksaan kadar $\mathrm{Hb}$ menggunakann alat pemeriksaan Hb Digital (haemoglobin testing system quick check),dan hasil penelitian dianalisis dengan menggunakan uji T dan Anova.

\section{HASIL PENELITIAN}

\section{A. Analisa Univariat}

Analisa univariat dari penelitian ini disajikan dalam tabel frekuensi dan dianalisis secara deskriftif.

1. Gambaran kadar Hb pada Siswi SMU di Kecamatan Medang Deras

Tabel 1. Distribusi Kadar Hb Remaja Putri di SMU

Medang Deras Kabupaten Batubara Tahun 2016

\begin{tabular}{|l|c|c|c|}
\hline $\begin{array}{l}\text { Nama } \\
\text { sekolah }\end{array}$ & $\begin{array}{l}\text { Jlh siswi } \\
\text { yang } \\
\text { diperiksa }\end{array}$ & $\begin{array}{l}\text { Jlh yang } \\
\text { anemia }\end{array}$ & Persentase \\
\hline SMA N I & 80 & 48 & $60 \%$ \\
\hline $\begin{array}{l}\text { SMA S } \\
\text { Citra }\end{array}$ & 73 & 48 & $65 \%$ \\
\hline $\begin{array}{l}\text { Aliyah } \\
\text { Alwasliyah }\end{array}$ & 62 & 44 & $70 \%$ \\
\hline Total & $\mathbf{2 1 5}$ & $\mathbf{1 4 0}$ & \\
\hline
\end{tabular}

Berdasarkan tabel diatas dapat diketahui bahwa mayoritas siswi di SMU yang ada di Kecamatan Medang Deras mengalami anemia, karena dari 215 siswi yang diperiksa 140 siswi $(65 \%)$ memiliki kadar $\mathrm{Hb}$ yang rendah (<12 gr/dl).

Tabel 2. Distribusi Rerata Kadar Hb Pre Dan Post Pada Remaja Putri di SMU Medang Deras Kabupaten Batubara Tahun 2016

\begin{tabular}{|l|l|c|c|c|}
\hline Variabel & Mean & SD & $\begin{array}{l}\text { Minimal- } \\
\text { Maksimal }\end{array}$ & 95\% CI \\
\hline $\begin{array}{l}\text { Kadar } \mathrm{Hb} \\
\text { Pre }\end{array}$ & 10.8 & 0.57 & $9.6-11.9$ & $10.7-11.0$ \\
$\begin{array}{l}\text { Kadar } \mathrm{Hb} \\
\text { Post }\end{array}$ & 11.5 & 0.64 & $10.0-12.9$ & $11.4-11.6$ \\
\hline
\end{tabular}

Hasil analisis didapatkan rata-rata kadar $\mathrm{Hb}$ remaja SMU di Medang Deras sebelum dilakukan intervensi sebesar 10.9 gr\% (95\% CI: 10.7-11.0), dengan standar deviasi $0.57 \mathrm{gr} \%$. Kadar $\mathrm{Hb}$ terendah $9.6 \mathrm{gr} \%$ dan tertinggi $11.9 \mathrm{gr} \%$. Dari hasil estimasi interval dapat disimpulkan bahwa $95 \%$ diyakini rata-rata kadar $\mathrm{Hb}$ remaja SMU di Medang Deras adalah diantara 9.6 $11.9 \mathrm{gr} \%$. Setelah dilakukan intervensi rata-rata kadar $\mathrm{Hb}$ remaja SMU di Medang Deras sebesar $11.5 \mathrm{gr} \%$ (95\% CI: 11.3-11.6), dengan standar deviasi $0.68 \mathrm{gr} \%$. Kadar $\mathrm{Hb}$ terendah 10.0 gr\% dan tertinggi $12.9 \mathrm{gr} \%$. Dari hasil estimasi interval dapat disimpulkan bahwa 95\% diyakini rata-rata kadar $\mathrm{Hb}$ setelah dilakukan intervensi diantara $10.0-12.9 \mathrm{gr} \%$.

\section{B. Analisa Bivariat}

1. Pengaruh pemberian Fe Kombinasi Vit $\mathrm{C}$ terhadap kadar Hb pada siswi SMU di Kecamatan Medang Deras

Tabel 3. Perbandingan Rata-Rata Kadar Hb Responden Sebelum dan Sesudah Pemberian fe Kombinasi Vit C pada Remaja Putri di SMU Medang Deras Tahun 2016

\begin{tabular}{|l|c|c|c|c|c|c|}
\hline \multicolumn{1}{|c|}{ Variabel } & Mean & $\begin{array}{c}\sum_{\text {Peningkata }} \\
\text { n Hb }\end{array}$ & SD & SE & P value & N \\
\hline $\begin{array}{l}\text { Kadar Hb } \\
\text { Sebelum } \\
\begin{array}{l}\text { Perlakuan } \\
\text { Setelah Perlakuan }\end{array}\end{array}$ & 11.3 & 0.6 & 0.55 & 0.55 & 0,001 & 37 \\
\hline
\end{tabular}

Rata-rata kadar $\mathrm{Hb}$ pada pengukuran sebelum perlakuan adalah 10,7 gr\% dengan standar deviasi 0.55 gr\%. Pada pengukuran setelah perlakuan didapat ratarata kadar $\mathrm{Hb}$ adalah 11.3 gr\% dengan standar deviasi $0.37 \mathrm{gr} \%$. Terlihat nilai mean perbedaan antara pengukuran pertama dan kedua adalah 0.6. Hasil uji statistik didapatkan nilai 0,001 maka dapat disimpulkan ada perbedaan yang signifikan antara kadar $\mathrm{Hb}$ pengukuran sebelum perlakuan dan sesudah dilakukan perlakuan 
2. Pengaruh pemberian Fe Kombinasi Vit A terhadap kadar Hb pada siswi SMU di Kecamatan Medang Deras

Tabel 4. Perbandingan Rata-Rata Kadar $\mathrm{Hb}$ Responden Sebelum dan Sesudah Pemberian fe Kombinasi Vit A pada Remaja Putri di SMU Medang Deras Tahun 2016

\begin{tabular}{|l|c|c|c|c|c|c|}
\hline \multicolumn{1}{|c|}{ Variabel } & Mean & $\begin{array}{c}\sum \text { Pening } \\
\text { katan Hb }\end{array}$ & SD & SE & P value & N \\
\hline $\begin{array}{l}\text { Kadar Hb } \\
\text { Sebelum } \\
\begin{array}{l}\text { Perlakuan } \\
\text { Setelah } \\
\text { Perlakuan }\end{array}\end{array}$ & 10.9 & 0.8 & 0.70 & 0.11 & 0,001 & 35 \\
\hline
\end{tabular}

Rata-rata kadar $\mathrm{Hb}$ pada pengukuran sebelum perlakuan adalah 10,7 gr\% dengan standar deviasi 0.55 gr\%. Pada pengukuran setelah perlakuan didapat ratarata kadar $\mathrm{Hb}$ adalah $11.3 \mathrm{gr} \%$ dengan standar deviasi $0.37 \mathrm{gr} \%$. Terlihat nilai mean perbedaan antara pengukuran pertama dan kedua adalah 0.6. Hasil uji statistik didapatkan nilai 0,001 maka dapat disimpulkan ada perbedaan yang signifikan antara kadar $\mathrm{Hb}$ pengukuran sebelum perlakuan dan sesudah dilakukan perlakuan.

3. Perbandingan hasil dari pemberian Fe dengan Vit $\mathrm{C}$ dan Fe dengan Vit A terhadap kadar $\mathbf{H b}$ pada siswi SMU di Kecamatan Medang Deras

Tabel 5. Distribusi Rata-Rata Kadar Hb Responden

Menurut Pengukuran Sebelum Perlakuan dan Sesudah

Perlakuan pada siswi di SMU Medang Deras Tahun

$$
2016
$$

\begin{tabular}{|l|l|l|l|l|l|}
\hline Variabel & Mean & SD & SE & $\begin{array}{l}\text { P } \\
\text { value }\end{array}$ & $\mathbf{N}$ \\
\hline Kadar Hb & & & & & \\
$\begin{array}{l}\text { Sebelum Perlakuan } \\
\text { Setelah Perlakuan }\end{array}$ & 10,8 & 0.64 & 0,63 & 0,001 & 105 \\
\hline
\end{tabular}

Rata-rata kadar $\mathrm{Hb}$ pada pengukuran pertama adalah 10,8 gr\% dengan standar deviasi 0.64 gr\%. Pada pengukuran kedua didapat rata-rata kadar $\mathrm{Hb}$ adalah 11.5 gr\% dengan standar deviasi 0.57 gr\%. Terlihat nilai mean perbedaan antara pengukuran pertama dan kedua adalah 0.66 dengan standar deviasi 0.45 . hasil uji statistik didapatkan nilai 0,001 maka dapat disimpulkan ada perbedaan yang signifikan antara kadar $\mathrm{Hb}$ pengukuran sebelum dilakukan perlakuan dan setelah dilakukan perlakuan.

Tabel 6. Distribusi Rata-Rata Peningkatan Kadar Hb Setelah dilakukan Perlakuan pada Remaja Putri di SMU Medang Deras Tahun 2016

\begin{tabular}{|l|c|c|c|c|}
\hline Variabel & Mean & SD & $\mathbf{9 5 \%}$ CI & $\begin{array}{c}\text { P } \\
\text { value }\end{array}$ \\
\hline $\begin{array}{l}\text { Fe Kombinasi } \\
\text { Fe }\end{array}$ & 11.5 & 0.63 & $11.3-11.7$ & 0.02 \\
Fe dan Vit C & 11.3 & 0.55 & $11.1-11.5$ & \\
Fe dan Vit A & 11.7 & 0.70 & $11.5-12.0$ & \\
\hline
\end{tabular}

Rata-rata kadar $\mathrm{Hb}$ responden yang diberikan fe sebesar 11.5 gr\% dengan standar deviasi $0.63 \mathrm{gr} \%$. Responden yang diberikan fe dengan vit $\mathrm{C}$ rata-rata kadar Hb sebesar 11.3 gr\% dengan standar deviasi 0.55 gr\%. Responden yang diberikan fe dengan vit A ratarata kadar $\mathrm{Hb}$ sebesar 11.7 gr\% dengan standar deviasi $0.70 \mathrm{gr} \%$. Hasil uji statistik didapat nilai $\mathrm{p}=0.02$, berarti pada alpha $5 \%$ dapat disimpulkan ada perbedaan rerata kadar $\mathrm{Hb}$ diantara ketiga kategori. Analisis Bonferroni membuktikan bahwa kelompok yang berbeda signifikan adalah kombinasi fe dan vit $\mathrm{C}$ dengan kombinasi fe dan vit A.

\section{PEMBAHASAN}

1. Gambaran kadar Hb pada Siswi SMU di Kecamatan Medang Deras

Hasil penelitian menunjukkan rerata kadar hemoglobin awal di sekolah menengah atas yang ada di kecamatan Medang Deras (SMA Negeri 1, SMA Swasta Citra dan Aliyah Alwasliyah) masih cukup rendah ( \pm 65 $\%$ siswi menderita anemia).

Banyaknya kasus anemia yang terjadi kemungkinan disebabkan oleh beberapa faktor meliputi asupan makanan dan pola makan, diantaranya karena kurangnya konsumsi zat besi $(\mathrm{Fe})$ dalam makanan seharihari yang dapat menimbulkan kekurangan darah yang dikenal dengan anemia gizi besi karena terganggunya pembentukan sel-sel darah merah sehingga konsentrasi hemoglobin dalam darah berkurang yang pada akhirnya menyebabkan anemia. Kelebihan zat besi jarang terjadi karena makanan, tetapi dapat disebabkan oleh suplemen besi, gejalanya seperti rasa muntah, diare, denyut jantung meningkat, sakit kepala, mengigau dan pingsan, selain itu, kelebihan zat besi bisa dipakai oleh mikroorganisme untuk pertumbuhannya (Almatsier, 2004).

Hasil wawancara dengan sampel terdapat banyak sampel yang asupan zat besinya kurang, karena makan tidak teratur dan tidak terbiasa sarapan pagi, hal ini disebabkan karena kebiasaan dirumah tangga yang tidak menyiapkan sarapan di pagi hari. Banyak siswi yang hanya sarapan dengan meminum satu gelas teh manis. Sedangkan untuk makan siang para siswi hanya makan seadanya sesuai apa yang tersedia. Factor sosialekonomi mungkin menjadi penyebab lain dari kurangnya asupan zat besi pada siswi yang ada di kecamatan Medang Deras karena mayoritas orangtua bekerja sebagai nelayan yang lebih mengutamakan menjual hasil tangkapannya kepada orang lain untuk mendapatkan uang baru membawa sisanya kerumah untuk dikonsumsi keluarga.

Di samping itu, kemungkinan terjadinya anemia bisa juga disebabkan oleh gangguan metabolisme zat besi dan zat mikro lainnya yang diperlukan tubuh serta interaksinya dalam tubuh.Interaksi zat gizi mikro dapat terjadi melalui dua mekanisme, yaitu: (i) satu jenis zat gizi mikro secara langsung mempengaruhi penyerapan zat gizi mikro lainnya, dan (ii) bila tubuh mengalami defisiensi atau kelebihan satu jenis zat gizi mikro baru mempengaruhi metabolisme zat gizi mikro lainnya ( Ridwan,E 2012)

Interaksi dapat terjadi di dalam makanan, pada fase penyerapan atau ketika di dalam tubuh. Makanan 
mengandung campuran berbagai zat gizi dan bahan bahan lain sehingga memungkinkan terjadinya interaksi zat gizi. Pada fase penyerapan, makanan dicerna dan zat gizi dilepas untuk dapat diserap. Selama proses pencernaan, zat gizi mikro mempengaruhi ketersediaan atau penyerapan zat gizi mikro lainnya, misalnya peningkatan daya larut atau oleh pengaturan fungsi usus. Bioavailabilitas zat besi meningkat bila dikonsumsi bersama dengan vitamin $\mathrm{C}$, karena vitamin $\mathrm{C}$ mereduksi zat besi (III/ferri) menjadi zat besi (II/ferro) yang lebih mudah diserap (Masthalina, 2015).

Faktor yang membantu penyerapan besi terdiri asam amino, asam organik (seperti vitamin C) juga vitamin A. Makanan yang menghambat absorpsi zat besi seperti kacang-kacangan mengandung asam fitat, teh/kopi mengandung tanin, buah-buahan mengandung pektin, bayam mengandung oksalat. Asam fitat yang terdapat pada kedelai dan oksalat dalam sayuran menurunkan absorpsi zat besi. Bahan makanan nabati cenderung membentuk endapan besi yang tidak larut sehingga besi tidak dapat diserap (Almatsier. 2004, Masthalina, 2015 ). Sebagian besar sampel dalam penelitian ini mempunyai kebiasaan minum teh. Tanin yang terdapat dalam teh dapat menghambat absorpsi besi.

\section{Pengaruh pemberian Fe Kombinasi Vit $\mathrm{C}$ terhadap kadar Hb pada siswi SMU di Kecamatan Medang Deras}

Hasil penelitian menunjukkan bahwa rerata kadar hemoglobin sampel meningkat setelah diberi perlakuan dan peningkatannya cukup signifikan $\mathrm{p}=0,001$. Sebelum intervensi rerata kadar $\mathrm{Hb}$ pada siswi dikecamatan Medang Deras adalah 10,7 gram/dL dan setelah intervensi rerata kadar hemoglobin adalah 11,3 gram/dL.

Sudah sejak lama diketahui vitamin C sebagai pemicu yang kuat terhadap penyerapan zat besi dari makanan dan memiliki kemampuan melawan efek penghambat dari fitat dan tanin. Beberapa penelitian menunjukkan efek positif dari vitamin $\mathrm{C}$ terhadap status zat besi, namun ada juga yang efeknya tidak seperti yang diharapkan. Ketidak samaan hasil penelitian tergantung dari karakteristik bahan pangan yang menjadi asupan seseorang (Masthaliana $\mathrm{H}$ dkk, 2015).

Beberapa hasil Penelitian sebelumnya yang di himpun oleh Ridwan E 2012 dalam kajiannya tentang interaksi zat besi menemukan penelitian yang dilakukan di India menunjukkan bahwa terjadi peningkatan $\mathrm{Hb}$ yang nyata setelah diberi $200 \mathrm{mg}$ vitamin $\mathrm{C}$ selama 60 hari pada anak penderita anemia yang konsumsi pangan nabatinya rendah vitamin $\mathrm{C}$ dan zat besi. Hal yang sama juga diungkapkan dari hasil penelitian bahwa dengan pemberian $50 \mathrm{mg}$ vitamin $\mathrm{C}$ setiap hari selama 8 minggu dapat memperbaiki status zat besi, tetapi pemberian suplementasi $2 \mathrm{~g}$ vitamin $\mathrm{C}$ yang diberikan pada orang dewasa dengan basis konsumsi daging, tidak menunjukkan perubahan status zat besi yang bermakna (Ridwan E, 2012). Hal ini menunjukkan bahwa pemberian Vitamin $\mathrm{C}$ akan memberikan makna jika asupan makan seseorang tidak terpenuhi dengan baik begitu juga dalam penelitian ini peningkatan kadar $\mathrm{Hb}$ yang terjadi setelah pemberian Fe dan Vitamin $\mathrm{C}$ bisa meningkat karena memang pada dasarnya sampel yang diteliti belum maksimal dalam pola makan. Ini terbukti dari informasi yang didapat bahwa banyak dari sampel yang makan tidak teratur dan bahkan jarang sarapan.

Penelitian lainnya yang dilakukan Fatimah dkk, 2011 menunjukkan bahwa anemia yang dialami ibu hamil berhubungan dengan asupan vitamin $\mathrm{C}$ yang kurang. Kurangnya Vitamin C pada seseorang juga dapat menyebabkan anemia, hal ini sejalan dengan penelitian yang dilakukan oleh Tadete A, dkk 2013 yang menyatakan terdapat hubungan antara vitamin $\mathrm{C}$ dengan kejadian anemia $(\mathrm{p}=0,042)$. Hasil penelitian ini menunjukkan peningkatan yang cukup signifikan terhadap kadar Hb sampel sehingga dapat diasumsikan bahwa Vitamin $\mathrm{C}$ berperan dalam meningkatkan penyerapan zat besi.

Zat besi banyak dijumpai pada sumber pangan baik hewani dan nabati. Zat besi non-heme banyak dijumpai pada sumber pangan nabati, dan merupakan sumber zat besi terbesar masyarakat di negara berkembang, termasuk di Indonesia. Vitamin $\mathrm{C}$ dapat meningkatkan penyerapan zat besi bila dikonsumsi dalam waktu bersamaan, karena vitamin $\mathrm{C}$ akan mengubah zat besi dari bentuk feri menjadi bentuk fero. Zat besi dalam bentuk fero lebih mudah diserap, selain itu vitamin $\mathrm{C}$ membentuk gugus zat besiaskorbat yang tetap larut pada $\mathrm{pH}$ lebih tinggi di dalam duodenum (Almatsier, 2006)

Beberapa penjelasan di atas menunjukkan bahwa efek vitamin $\mathrm{C}$ dalam meningkatkan kadar zat besi, tidak hanya tergantung pada status zat besi pada awal penelitian, tetapi juga sangat dipengaruhi oleh bahan-bahan lain yang terdapat dalam makanan yang dikonsumsi dan dapat mempengaruhi penyerapan zat besi. Hasil penelitian ini sesuai dengan hasil penelitian terdahulu bahwa pemberian zat besi dan Vitamin C merupakan suplementasi yang dapat diberikan pada penderita anemia karena terbukti rerata $\mathrm{Hb}$ meningkat setelah diberi perlakuan.

Alasan lain adanya peningkatan rerata kadar hemoglobin pada sampel yang diberikan tablet tambah darah dan atau vitamin C karena kepatuhan responden minum tablet zat besi yang diberikan secara teratur. Pada penelitian ini hasil yang didapat juga menunjukkan peningkatan kadar $\mathrm{Hb}$ setelah diberikan Fe dan Vitamin C, namun ada juga subjek yang mengalami perubahan kadar hemoglobin, tetapi belum mencapai nilai kadar hemoglobin normal (12 gram/dL). Hal tersebut dapat terjadi antara lain karena asupan nutrisi yang tidak teratur dan proses menstruasi yang terjadi pada sampel yang bisa menyebabkan kadar $\mathrm{Hb}$ tidak mencapai kadar normal,

Penyerapan besi dipengaruhi oleh banyak faktor, Protein hewani dan vitamin $\mathrm{C}$ meningkatkan penyerapan. Kopi, teh, garam kalsium, magnesium dapat mengikat zat besi sehingga mengurangi jumlah serapan. Sebaiknya, tablet zat besi ditelan bersamaan dengan makanan yang 
dapat memperbanyak jumlah serapan, sementara makanan yang mengikat zat besi sebaiknya dihindarkan atau tidak dimakan dalam waktu bersamaan. Perlu diperhatikan bahwa pemberian tambahan besi sebaiknya diperoleh dari makanan karena tablet zat besi terbukti dapat menurunkan kadar mineral seperti seng dalam serum (Ridwan E, 2012).

Saat ini penanggulangan anemia terutama pada remaja sudah dilakukan secara nasional dengan pemberian pil zat besi selama 3 bulan yang diminum setiap hari (Arumsari E, 2008), namun kebijakkan tersebut belum menjangkau siswi yang ada di kecamatan Medang deras sehingga masih banyak yang menderita anemia. Suplementasi zat besi menjadi salah satu cara untuk meningkatkan hemoglobin darah dan kesehatan remaja wanita apalagi jika dikombinasikan dengan factor enhancer dari penyerapan zat besi tersebut. Zat besi di dalam bahan makanan dapat berbentuk hem yang berikatan dengan protein dan terdapat dalam bahan makanan yang berasal dari hewani. Lebih dari $35 \%$ hem ini dapat diabsorpsi langsung. Bentuk lain adalah dalam bentuk nonhem yaitu senyawa besi anorganik yang kompleks yang terdapat di dalam bahan makanan yang berasal dari nabati, yang hanya dapat diabsorbsi sebanyak 5\%. Zat besi yang dimakan bersama dengan makanan akan ditolelir lebih baik meskipun jumlah zat besi yang diserap berkurang. Vitamin $\mathrm{C}$ dapat berperan meningkatkan absorbsi zat besi nonheme menjadi empat kali lipat. Vitamin $\mathrm{C}$ dan zat besi membentuk senyawa askorbat besi kompleks yang mudah larut dan mudah diabsorbsi (Yanagishawa et al, 2009) Penelitian terdahulu juga mengindikasikan bahwa ada hubungan yang bermakna antara peningkatan kadar hemoglobin dengan konsumsi vitamin $\mathrm{C}$, zat besi nonheme akan meningkat 2-20\% bila mengkonsumsi vitamin $\mathrm{C}$ (Utama dkk, 2013).

\section{Pengaruh pemberian Fe Kombinasi Vit A terhadap kadar Hb pada siswi SMU di Kecamatan Medang Deras}

Berdasarkan hasil penelitian yang dilakukan terhadap 35 sampel yang mengalami anemia (nilai $\mathrm{Hb}$ dibawah $12 \mathrm{mg} / \mathrm{dl}$ ) didapatkan terjadi peningkatan $\mathrm{Hb}$ secara signifikan. Hal ini berdasarkan uji statistic yang dilakukan dengan menggunakan uji $\mathrm{T}$ independent, didapatkan nilai $\mathrm{p}=0,001(<0,05)$. Hal ini menjelaskan bahwa terdapat pengaruh yang bermakna antara pemberian $\mathrm{Fe}+$ Vit A terhadap peningkatan Hemoglobin

Peningkatan hemoglobin pada sampel dapat disebabkan oleh karena adanya hubungan pemberian fe dan vitamin A yang dapat meningkatkan nilai hemoglobin. Hal ini sesuai dengan teori yang menyatakan bahwa vitamin A dan Fe cukup berinteraksi dengan cara melakukan mobilisasi pada besi dari hati (Machlin dan Langseth, 1998). Penelitian ini juga sejalan dengan pendapat Asterina tahun 2009 mengenai pengaruh $\mathrm{Fe}$ dan vitamin A pada anemia anak usia sekolah di Padang menunjukkan bahwa terdapat pengaruh dalam peningkatan hemoglobin pada anak usia sekolah yang mengalami anemia dibandingkan dengan anak yang hanya diberi Fe.

Kekurangan vitamin A dapat memperburuk anemia kurang zat besi. Pemberian suplementasi vitamin A memiliki efek menguntungkan pada anemia kurang zat besi. Kombinasi suplemen vitamin A dan zat besi pada penelitian ini terbukti dapat mengurangi anemia dan mungkin lebih efektif daripada pemberian suplemen zat besi atau vitamin A secara terpisah

Vitamin A mempunyai banyak peran di dalam tubuh, antara lain untuk pertumbuhan dan diferensiasi sel progenitor eritrosit, imunitas tubuh terhadap infeksi dan mobilisasi cadangan zat besi dari seluruh jaringan. Interaksi vitamin A dengan zat besi bersifat sinergis, hal ini terlihat ketika pemberian vitamin A dapat menurunkan prevalensi anemia dan memperbaiki utilisasi zat besi dibandingkan hanya dengan suplementasi vitamin A saja atau dengan zat besi saja. Kemudian seorang peneliti juga menemukan bahwa, bila tubuh dalam keadaan kekurangan vitamin A, maka transportasi zat besi dari hati dan atau penggabungan zat besi ke dalam eritrosit terganggu (Semba RD, 2002)

Beberapa hasil penelitian yang di rangkum oleh FAO/WHO 2004, mengungkapkan bahwa kekurangan vitamin A mempengaruhi metabolisme zat besi. Interaksi vitamin A dengan zat besi juga ditunjukkan dari hasil penelitian ketika suplementasi vitamin A diberikan pada anak sekolah yang menderita kekurangan zat besi dan vitamin A. Hasil penelitian menunjukkan bahwa terjadi interaksi vitamin A terhadap zat besi yang ditandai dengan prevalensi anemia menurun, serum tranferin reseptor menurun, yang berarti memperbaiki erythropoiesis.

Hal senada juga ditunjukkan oleh hasil penelitian yang menunjukkan bahwa $\mathrm{Hb}$ meningkat lebih tinggi pada kelompok yang diberi vitamin A dengan zat besi, dibandingkan dengan kelompok yang hanya diberi zat besi (Parmaesih D dkk, 2011).Vitamin A terlibat dalam pengaturan pengeluaran zat besi dari hati. Hasil penelitian mengungkapkan bahwa suplementasi vitamin A dengan zat besi memperbaiki status vitamin A dan memperbaiki status zat besi lebih baik daripada jika disuplementasi dengan zat besi atau dengan vitamin A saja.

\section{Perbandingan hasil dari pemberian Fe dengan Vit C dan Fe dengan Vit A terhadap kadar $\mathbf{H b}$ pada siswi SMU di Kecamatan Medang Deras}

Hasil penelitian ini menunjukkan bahwa ada peningkatan kadar $\mathrm{Hb}$ setelah dilakukan intervensi berupa suplementasi zat besi pada responden selama 4 minggu. Dari hasil uji statistic diketahui nilai $\mathrm{p}=0,002$. Dari ketiga kelompok perlakuan juga menunjukkan bahwa ada peningkatan kadar $\mathrm{Hb}$ setelah pemberian suplementasi. Hal ini dikarenakan dengan suplementasi selama 4 minggu dapat meningkatkan asupan $\mathrm{Fe}$ sehingga dapat meningkatkan kadar Hb sampel Rerata peningkatan kadar $\mathrm{Hb}$ sampel dari masing-masing perlakuan (1) pemberian $\mathrm{Fe}$ sebesar 11,5 g/dl , perlakuan (2) pemberian Fe dengan Vit $\mathrm{C}$ sebesar 11,3 g/dl dan perlakuan (3) pemberian Fe dengan Vit A sebesar 11,7 g/dl. Hal ini sesuai dengan hasil penelitian sebelumnya yang menyatakan bahwa pemberian suflementasi $\mathrm{Fe}$ dan zat gizi mikro lainnya seperti 
vitamin A dan Vitamin C dapat meningkatkan kadar Hb (Asterina 2009, Ridwan E. 2009, Utama dkk.2013)

Hal ini sesuai dengan teori bahwa pemberian suplementasi Fe akan meningkatkan oksigenasi dalam sel menjadi lebih baik, metabolism meningkat dan fungsi sel akan optimal sehingga daya serap makanan menjadi lebih baik (Almatsier 2006). Besi mempunyai beberapa fungsi esensial di dalam tubuh yaitu sebagai alat angkut oksigen dari paru-paru ke jaringan tubuh, sebagai alat angkut elektron di dalam sel, dan sebagai bagian terpadu berbagai reaksi enzim di dalam jaringan tubuh. Walaupun terdapat banyak dalam makanan namun banyak penduduk dunia mengalami kekurangan besi termasuk di Indonesia.

Besi dalam makanan terdapat dalam bentuk besi hem seperti hemoglobin dan mioglobin makanan hewani Besi hem diabsorpsi ke dalam mukosa sel sebagai kompleks porfirin utuh. Cincin porfirin di dalam sel mukosa kemudian dipecah oleh enzim khusus (hemoksigenase) dan besi dibebaskan. Besi hem dan non hem kemudian melewati alur yang sama dan meninggalkan sel mukosa dalam bentuk sama dengan menggunakan alat angkut yang sama. Absorpsi besi hem tidak banyak dipengaruhi komposisi makanan dan sekresi saluran cerna serta oleh status besi seseorang. Besi hem hanya merupakan bagian kecil dari besi yang diperoleh dari makanan (kurang lebih $5 \%$ dari besi total makanan), terutama di Indonesia, namun yang dapat diabsorpsi dapat mencapai $25 \%$ sedangkan non hem hanya $5 \%$ (Almatsier, 2006).

Pemberian Kombinasi Vitamin C dapat meningkatkan penyerapan $\mathrm{Fe}$ karena Vitamin $\mathrm{C}$ akan mempermudah perubahan zat besi dari bentuk feri menjadi fero begitu juga kombinasi vitamin A dengan Fe akan meningkatkan penyerapan zat besi karena vitamin A berperan dalam pengaturan pengeluaran zat besi dari hati. Namun jika dibandingkan hasil penelitian yang didapat di Kecamatan Medang deras terlihat bahwa kombinasi vitamin A dan fe memiliki rerata yang paling besar dan hal ini menunjukkan bahwa hipotesa penelitian ini ditolak.

Hasil perbandingan rerata kadar $\mathrm{Hb}$ pada siswi di SMA yang ada dikecamatan Medang Deras menunjukkan bahwa pemberian $\mathrm{Fe}$ dan vitamin A menunjukkan rerata yang lebih besar dibanding 2 kelompok perlakuan lainnya (Fe dan Fe kombinasi Vitamin C) hal ini kemungkinan besar bisa disebabkan karena faktor asupan makan dari sampel yang ada dikecamatan Medang yang cenderung lebih sedikit mengandung vitamin A dibanding vitamin C yang pada umumnya banyak terdapat pada buah-buahan sehingga ketika diberi suflementasi Vitamin A terjadi perbedaan peningkatan kadar $\mathrm{Hb}$ yang lebih besar pada kelompok Fe dan Vitamin A. Pemberian vitamin A juga dapat mencegah terjadinya penyakit infeksi karena vitamin A dapat berperan sebagai progenitor eritrosit yang dapat meningkatkan imunitas sehingga dapat mempermudah penyerapan fe (Ridwan E, 2012), kondisi seseorang yang menderita infeksi cenderung membuat penyerapan zat besi menurun. Dengan adanya pemberian vitamin A maka kemungkinan infeksi dapat dicegah sehingga penyerapan fe bisa lebih maksimal. Namun hal ini seharusnya didukung oleh pemeriksaan yang lebih spesifik untuk melihat tingkat infeksi yang terjadi pada sampel sehingga hal ini bisa lebih jelas. Pada penelitian ini juga tidak dilakukan food recall sehingga sulit untuk menentukan penyebab pasti dari factor yang mempengaruhi penyerapan baik zat besi maupun vitamin yang dikombinasikan.

\section{Kesimpulan}

1. Rerata kadar $\mathrm{Hb}$ pada siswi SMU yang ada di Kecamatan Medang deras mayoritas dibawah normal $(<12 \mathrm{gr} / \mathrm{dl})$ sebelum diberi perlakuan dan mengalami peningkatan setelah diberi perlakuan.

2. Kombinasi suplementasi vitamin A dengan zat besi dapat diberikan karena berinteraksi secara sinergis sehingga dapat meningkatkan kadar $\mathrm{Hb}$ sampel yang diteliti.

3. Suplementasi kombinasi antara vitamin $\mathrm{C}$ dan zat besi akan memberikan dampak yang nyata berupa kenaikan penyerapan zat besi sehingga dapat meningkatkan kadar $\mathrm{Hb}$.

4. Besarnya rerata peningkatan kadar $\mathrm{Hb}$ dijumpai lebih tinggi pada kelompok yang diberi perlakuan $\mathrm{Fe}+\mathrm{Vit} \mathrm{A}$.

\section{Saran}

1. Perlu dilakukan penelitian lebih lanjut terkait jumlah asupan gizi, zat besi, protein, dan zat gizi mikro lainnya, sehingga peneliti bisa menggali lebih dalam dan lebih detail tentang jumlah konsumsi makanan yang berhubungan dengan kejadian anemia.

2. Kegiatan ini dapat dilanjutkan dengan melaksanakan kegiatan pengabdian masyarakat berupa pemeriksaan kadar $\mathrm{Hb}$ secara rutin, penyuluhan, pemberian tablet fe dan Vitamin bagi yang anemia guna mendukung upaya pemerintah dalam menurunkan angka anemia pada remaja.

\section{DAFTAR PUSTAKA}

Adriana, 2010, Faktor-Faktor yang Berhubungan dengan Kejadian Anemia Remaja Putri di Madrasah Aliyah Negeri 2 Bogor, Skripsi , UIN Syarif Hidayatullah, Jakarta.

Almatsier, S. (2006). Prinsip Dasar Ilmu Gizi. Gramedia : Jakarta.

Almatsier, S. (2004). Prinsip Dasar Ilmu Gizi. Gramedia : Jakarta

Al-Sharbatti, S.S., Al-Ward, N. \& Al-Anm, D.J. (2000) Anemia among Adolescent. smj, pp. 1167-1171.

Anderson J., Fitzgerald C, 2010, Iron: An Essetial Nutrient. Colorado. Colorado State University.

Andrews, C.N, 2005, Understanding Heme Transport, N. Engl.J.Med, Boston (23) : 2508-2509.

Argana,G., Kusharisupeni dan Utari Diah . 2004. Vitamin C Sebagai Faktor Dominan Untuk Kadar Hemoglobin Pada Wanita Usia 20 - 35 Tahun. J Kedokter Trisakti, 23 (1). Hal 6-14.

Arumsari E, 2008, Faktor Risiko Anemia Pada Remaja Putri Peserta Program Pencegahan Dan Penanggulangan Anemia Gizi Besi (Ppagb) Di Kota 
Bekasi, Program Studi Gizi Masyarakat Dan Sumberdaya Keluarga Fakultas PertanianInstitut Pertanian Bogor

Asterina, Sari YK, 2009 Pengaruh Pemberian Fe + Vitamin A Terhadap Peningkatan Hemoglobin Pada Anak Usia Sekolah Yang Mengalami Anemia Di SD 42 Beringin Kelurahan Air Dingin Padang.

Bailo B; Sohemy A; Haddad P; Arora P; Benzaied F; Kamali M; Badawi A, 2011, Vitamin D,C, and E in The Prevention of Type 2 Diabetes Mellitus : Modulation of Imflammation and Oxidative Stress, Biologics ; Targets \& Therapy, Dove Press Journal, 18 January 2011.

Beard, J. L. (2001) Iron Biology in Immune Fuction, Muscle Metabolism and Neural Functioning. J. Nutr, 131 (2S-2), pp 568S-579S.

Bhargava, A., Bouis, H.E. \& Scrimshaw, N.S. (2001) Dietary Intakes and Socioeconomic Factors are Associated with the Hemoglobin Concentration of Bangladeshi Women. J. Nutr, pp. 758-764.

FAO \& WHO. 2004, Joint FAO/WHO Expert Consultation on Human Vitamin and Mineral Requirements. Vitamin and Mineral Requirements in human nutrition, 2nd edition. Geneva

Fatimah dkk, 2011, Pola Konsumsi Dan Kadar Hemoglobin Pada Ibu Hamil Di Kabupaten Maros, Sulawesi Selatan, Makara, Kesehatan, Vol. 15, No. 1, Juni 2011: 31-36

Guyton, Arthur C , 1996. Buku Ajar Fisiologi Kedokteran. EGC : Jakarta.

Hoffbrand A.V, Pettit JE, Moss PAH, (2005) Kapita Selekta Hematologi edisi 4.EGC. Jakarta.

Ibrahim D, 2005, Oral Iron Supplements : A Reiview, University of Saskatchewan Pharmacy \& Nutrition.

Jourkesh M; Sadri I ; Sahranavand A; Ojagil A ; Dehyanpoori M, 2011, The Effects of Two Different doses of Antioxidant Vitamin $C$ Supplementation on Bioenergetics Index in Male College Student, Journal of American Science, (6): 852-858.

Khadafi dkk, 2015 Pengaruh Pemberian Tablet Besi Dan Vitamin C Terhadap Kadar Hemoglobin Mahasiswi S1 Keperawatan , Skripsi, FIK Universitas Muhammadiyah Surakarta.

Kaur, S, Deshmukh, P.R. \& Garg, B.S. (2006) Epidemiological Correlates of Nutritional Anemia in Adolescent Girls of Rural Wardha. Indian Journal of Community Medicine, 31 (4), pp. 255258.

Kemenkes RI, 2013, Riset Kesehatan Dasar. Laporan Nasional 2013. Jakarta. Badan Penelitian dan Pengembangan Kesehatan Departemen Kesehatan Republik Indonesia.

Kodiyat, 2008. http://www.inspiredkidsmagazine.com/ Anakpun Terkena Anemia diakses 28 januari 2011.

Lestari,D, 2008, Uji Toleransi Lambung terhadap Ferro Sulfat yang Diberikan dalam Cangkang
Kapsul Alginat pada Penderita Anemia Deffisiensi Besi. Tesis. Pascasarjana Universitas Sumatera Utara. www.usu.library.com. Diakses tanggal 1 Oktober 2011.

Machlin,L, J \& L.Langseth 1998. Vitamin interactions. Dalam Bodwell,Ce,\&J.W. eDW

Masita, 2008, Hubungan citra tubuh dengan kejadian anemia pada remaja di kabupaten Purworejo, Tesis UGM, Yogyakarta.

Masthalina dkk, 2015 Pola Konsumsi (Faktor Inhibitor Dan Enhancer Fe) Terhadap Status Anemia Remaja Putri, Jurnal Kesehatan Masyarakat (KESMAS) 11 (1) (2015) 80-86.

Mikail B ;Candra A, 2011, Anemia dan Tubuh Pendek Masih Mengancam. www.health.kompas.com. Diakses tanggal 1 Nopember 2011.

Permaesih dkk 2011, Pengaruh Suplementasi Zat Gizi Mikro Terhadap Status Besi Dan Status Vitamin A Pada Siswa SLTP, Gizi Indon, 34(1):14-22.

Pradanti dkk 2015, Hubungan Asupan Zat Besi (Fe) Dan Vitamin C Dengan Kadar Hemoglobin Pada Siswi Kelas VIII SMP Negeri 3 Brebes, Jurnal Gizi Universitas Muhammadiyah Semarang, Volume 4, Nomor 1.

Price S.A, 2007, Patofiisologi, Jakarta, Penerbit EGC.

Rajaratnam, J., Abel, R., Asokan, J.S. \& Jonathan, P. (2000) Prevalence of Anemia Among Adolescent Girls of Rural Tamilnadu. Indian Pediatr, 37, pp.532-536.

Ridwan E. 2012, Kajian Interaksi Zat Besi Dengan Zat Gizi Mikro Lain Dalam Suplementasi (Review Of Interactions Between Iron And Other Micronutrients In Supplementation), Penel Gizi Makan , 35(1): 49-54

Sacher R ; McPherson R, 2004, Tinjauan Klinis Hasil Pemeriksaan Laboratorium, EGC, Edisi 11, Cetakan 1 Hal 33.

Sari N.H, 2011, Manfaat Vitamin C. http://pusatmdis.cm/manfaat_dan resiko suplemen_vitamin_c_616.htm diakses 29 Nopember 2011.

Semba RD, Bloem MW. The anemia of vitamin A deficiency: epidemiology and pathogenesis. Eur J Clin Nutr. 2002; 56(4): 271-81

Shils, M.E., Olson, J.A., Shike, M. \& Ross, A.C. (2005) Modern Nutrition in Health and Disease. Lippincott Williams \& Wilkins, Philadelphia.

Sloan E,1996, Anatomi dan Fisiologi, Jakarta, Penerbit EGC.

Soemardjo D, 2009, Vitamin dan Biomineral dalam Pengantar Kimia Buku Panduan Kuliah Mahasiswa Kedokteran dan Program Strata 1Fakultas Bioeksakta. Jakarta. EGC. Cetakan I. Hal 351-388.

Stang, J. \& Story, M. (2005) Guidelines for Adolescent Nutrition Services. Center for Leadership, Education and Training in Maternal and Child Nutrition, Devision of Epidemiology and Community Health, School of Public Health, University of Minnesota, Minneapolis. 
Tadeta A, dkk 2013, Hubungan Antara Asupan Zat Besi, Protein Dan Vitamin C Dengan Kejadian Anemia Pada Anak Sekolah Dasar Di Kelurahan Bunaken Kecamatan Bunaken Kepulauan Kota Manado, Fakultas Kesehatan Masyarakat Universitas Sam Ratulangi Manado

Utama dkk, 2013 Perbandingan Zat Besi dengan dan Tanpa Vitamin C, Jurnal Kesehatan Masyarakat Nasional Vol. 7, No. 8, Maret 2013, Hal 344-348.

WHO. (2001) Nutrition in Adolescent-Issues and Challenges for the Health Sector: Issues in Adolescent Health and Development. Geneva
Yanagishawa, et al. 2009 Long-term intake of a high zinc diet causes iron deficiency anemia accompanied by reticulocytosis and extramedullary erythropoiesis. Toxicology Letters; 191(1): 15-19. 